\title{
Resources partitioning in a fruit bat community of the southern Atlantic Forest, Brazil
}

\author{
Marcelo de Moraes Weber ${ }^{1, *}$, Jeferson L. Steindorff \\ de Arruda', Bethânia Oliveira Azambuja², Vagner \\ Luis Camilotti ${ }^{2}$ and Nilton Carlos Cáceres $^{3}$ \\ ${ }^{1}$ Programa de Pós-Graduação em Biodiversidade Animal, \\ Universidade Federal de Santa Maria, Av. Roraima 1000, \\ 97105-900, Santa Maria, Rio Grande do Sul, Brazil, \\ e-mail: marcelo_weber@yahoo.com.br \\ ${ }^{2}$ Programa de Pós-Graduação em Ecologia, Universidade \\ Federal do Rio Grande do Sul, Av. Bento Gonçalves, 9500, \\ Campus do Vale, Porto Alegre, Rio Grande do Sul, \\ 91501-970, Brazil \\ ${ }^{3}$ Laboratório de Ecologia de Aves e Mamíferos, \\ Departamento de Biologia, Universidade Federal de Santa \\ Maria, Camobi, Santa Maria, Rio Grande do Sul, \\ 97105-900, Brazil \\ *Corresponding author
}

\begin{abstract}
Bat species have differences in diet composition, use of vertical space, and nocturnal activity period. We analyzed diet and partitioning of spatial and temporal resources among fruit bats, and the influence of fruit availability on the number of bat captures in the southern boundary of the Atlantic Forest. Artibeus lituratus and A. fimbriatus fed mainly on Ficus, whereas Sturnira lilium fed on Solanaceae, Piperaceae, and Ficus. However, we did not find correlation between number of fruit bat captures with fruit availability. $S$. lilium was more active at dusk, whereas A. fimbriatus and A. lituratus were more active at dawn. S. lilium flew more in the understory than canopy and A. lituratus and A. fimbriatus did not show differences in the use of vertical space. There was no difference in the use of vertical space among these fruit bats. We showed that differences in one dimension of the niche, such as food, can help to explain differences in another dimension, such as space use. Niche overlap is greater for related species and studies about niche overlap addressing more than one spatial dimension can elucidate the patterns in use of these resources and also the understanding about bat community composition.
\end{abstract}

Keywords: coexistence; fruit bats; niche differentiation; nocturnal activity period; vertical stratification.

\section{Introduction}

Coexistence of different species in the same place is assigned to variation in the use of spatial, temporal, and food resources by the organisms (Hutchinson 1957). Resources partitioning decreases the interspecific competition and it allows the species coexistence (MacArthur 1972), but in a small geographical area, this coexistence can result in a spatial-temporal overlap of some species (Giacomini 2007).

Neotropical bats are very abundant and biologically diverse, with different and significant ecological roles in the biological communities (Marinho-Filho and Sazima 1998), such as seed dispersal, flower pollination, and control of insect populations (Kunz 1982a, Findley 1993, Kunz and Fenton 2003). Variations in the abundance and species composition of frugivorous bats are related to food availability (Hodgkison et al. 2004). Species that feed on fruits available throughout the year are captured continually while species which forage on temporary resources are found intermittently. Therefore, there is a temporal variation in the species composition of fruit bats (Hodgkison et al. 2004).

Temporal variation in the species composition could be related with striking differences in diet of fruit bats. Congeneric bats seem to feed on plants of the same genus or family. For instance, Carollia prefers Piper fruits (Fleming 1991, Mello et al. 2004a), Sturnira forages primarily on Solanaceae fruits (Mello et al. 2008), and species of Artibeus forage on Moraceae fruits (Bonaccorso 1979, Galetti and Morellato 1994, Passos and Graciolli 2004). Diet differences among bat genera are well known; however, studies about the differences between related sympatric species are still scarce.

Beyond the differences in diet, bats also can use vertical space in different ways (Simmons and Voss 1998, Bernard 2001, Kalko and Handley 2001, Henry et al. 2004). According to Bernard (2001), bats can be classified as: (1) canopy specialists; (2) understory specialists; (3) opportunistic, those that use both strata; and (4) high flyers, species that fly above the canopy with sporadic incursions into gaps (members of the family Molossidae). Unfortunately, most studies are carried out at ground-level nets and this method samples only a subset of the fauna. In tropical forests, where the canopy may reach 30-60 $\mathrm{m}$ above the ground, the structure of bat communities at ground level may not be representative of the community as a whole (Francis 1994). Because of their structural complexity, canopies are among of the most diverse parts of tropical forests, but due to their inaccessibility, they are also the least understood (Kalko and Handley 2001). In bat ecology, flying low in the forest may be advantageous for avoiding potential predators, such as owls (Bonaccorso 1979, Handley et al. 1991). Also, understory has high abundance of fruiting shrubs and other plants in Neotropical forests (Fleming et al. 1987). Alternatively, flying high may provide access to bigger fruits in the canopy, 


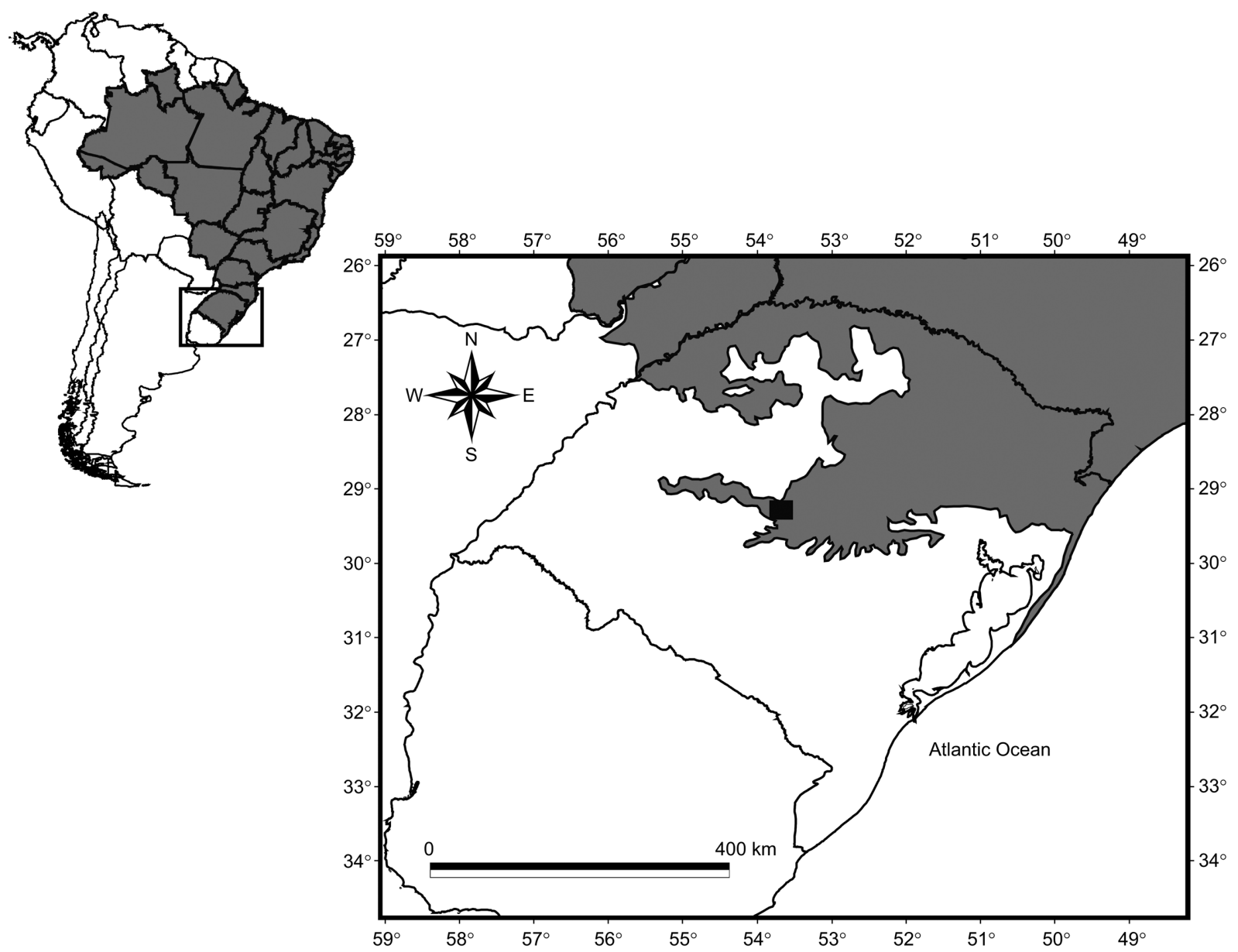

Figure 1 Study area (black square) located at the boundary of the Atlantic Forest (gray area) in a deciduous forest, Santa Maria, Rio Grande do Sul, southern Brazil.

which are unavailable in the understory (Gentry and Emmons 1987).

Bats that use the same food resources and the same vertical space can fly at different times (Hooper and Brown 1968). Time can be used by species in different ways, such as variation throughout the year or periods of the night (Marinho-Filho and Sazima 1989, Aguiar and Marinho-Filho 2004, Ortencio Filho et al. 2010). Fruit bats tend to be more active in the evening. This may decrease the intra- and interspecific competition, since once it has been eaten a fruit cannot be replaced and the number of ripe fruits tend to decrease through the night (Marinho-Filho and Sazima 1989). Nectarivorous bats do not show a strong activity pattern because nectar is easily replaced in a short time by the plant (Marinho-Filho and Sazima 1989, Aguiar and Marinho-Filho 2004). Different activity periods avoid encounters among potential competitors that use the same food or spatial resource (Kronfeld-Schor and Dayan 2003). All these variations on diet, space and time allow coexistence of sympatric species with similar niches.

Therefore, the goals of this study were to analyze: (1) the diet composition of fruit bats and the influence of fruit avail- ability on bat captures; and (2) the vertical space use and nocturnal activity period of these bats in the southern boundary of the Atlantic Forest. This can highlight the understanding about Neotropical bat communities and resource partitioning among sympatric species.

\section{Materials and methods}

\section{Study area}

Rio Grande do Sul is located in the transition of tropical and subtropical climate zones (Marchiori 2004). This state has three biogeographic regions: Atlantic, Paranaense, and Pampeana provinces (Waechter 2002). The study area is located in Santa Maria $\left(53^{\circ} 30^{\prime}-54^{\circ} 19^{\prime} \mathrm{W}, 29^{\circ} 20^{\prime}-30^{\circ} 00^{\prime} \mathrm{S}\right)$, which is in the transitional area between Pampeana and Paranaense provinces, and between Brazilian Meridional Plateau and Central Depression of Rio Grande do Sul, with 500 m maximum altitude (northward) and $40 \mathrm{~m}$ minimum (southward) (Pereira et al. 1989). The area is known locally as "Morro do Elefante", (Figure 1) and the top of this mount is $462 \mathrm{~m}$ 
and its base is $119.4 \mathrm{~m}$ above sea level $\left(29^{\circ} 40^{\prime} \mathrm{S}, 53^{\circ} 43^{\prime}\right.$ $\mathrm{W})$. The site is approximately $2 \mathrm{~km}$ from an urban area and is used as a nature trail occasionally. The lower area is used for cattle grazing and Pinus and Eucalyptus plantations. Vegetation is classified as Seasonal Forest (Quadros and Pillar 2002), and the arboreal vegetation is composed mainly of species of Leguminosae, Lauraceae, Myrtaceae and Meliaceae (Machado and Longhi 1990).

During the study, annual rainfall was $1534 \mathrm{~mm}$ and annual mean temperature was $19.86^{\circ} \mathrm{C}$ (data from Climate Station of the Phytotechnical Department, Universidade Federal de Santa Maria, located $6 \mathrm{~km}$ from the study area).

\section{Methods}

We selected two sampling sites in the study area. The first was located at the bottom of the mount, $100 \mathrm{~m}$ from the forest edge ( $262 \mathrm{~m}$ altitude), and the second one at the top of the mount (462 $\mathrm{m}$ altitude).

We carried out bat captures every month (January to December 2005) for four consecutive nights per month, two nights at each site. Bats were captured with seven mist-nets (with $7 \times 2 \mathrm{~m}$ ), five placed between $0.5 \mathrm{~m}$ and $2 \mathrm{~m}$ above the ground, and two (one below the other) settled immediately above the canopy, at about $15 \mathrm{~m}$ above the ground. This was possible because we attached mist-nets to sticks, which were fastened to the higher branches in the canopy. Eventually, we cut some branches to facilitate the vertical movement of the sticks with the mist-nets. Mist-nets remained open for three hours after nightfall. We also sampled for $1 \frac{1}{2} \mathrm{~h}$ before dawn in one night at each site per month. Mist-nets were settled in trails and in open areas in the middle of the forest, and we checked the nets every $15 \mathrm{~min}$. We avoided sampling during the full moon because some bat species are less active at this time (Crespo et al. 1972). To measure the sampling effort we followed Straube and Bianconi (2002): sampling $180 \mathrm{~h}$ with $98 \mathrm{~m}^{2}$ of open net per hour, a total of $17,640 \mathrm{~m}^{2} / \mathrm{h}$. In the understory we sampled $12,600 \mathrm{~m}^{2} / \mathrm{h}$ and in the upper canopy we sampled $5040 \mathrm{~m}^{2} / \mathrm{h}$. After capture, we identified the bats according to Vizotto and Taddei (1973) and Barquez et al. (1993). We also recorded the time and stratum where the animal was captured. Frugivorous species were placed in cloth bags for $20 \mathrm{~min}$ to collect feces and analyze the diet. We marked the animals with a colored necklace and then released them. We also collected one voucher specimen of each species to deposit in the Zoological Collection of the Universidade Federal de Santa Maria.

Fruit availability was analyzed with 42 fruit collectors set out in two $60 \times 150 \mathrm{~m}$ grids, one at the bottom and other at the top of the mount, at the same sampling sites where we settled the mist-nets. Each collector-grid was composed by seven trails with three fruit collectors each one, with $25 \mathrm{~m}$ between collectors, and $30 \mathrm{~m}$ between each trail. Fruit collectors were made with fabric in a conical form of $1 \mathrm{~m}$ in diameter, and they were placed $1 \mathrm{~m}$ above the ground. Fabric allows the water passage when it rains, and it preserves the fruits until the removal from collectors, which occurred each
15 days. Fruits and seeds found inside the collectors were identified to assess the monthly availability of fruit species.

\section{Statistical analysis}

We analyzed partitioning of spatial and temporal resources only for Artibeus fimbriatus, A. lituratus, and Sturnira lilium, which had sufficient capture data. To analyze nocturnal activity period, we considered only those nights sampled during dawn $(n=24$ nights). The differences in time division (three periods of $1 \frac{1}{2} \mathrm{~h}$ ) among bat species throughout night were analyzed by G-test (Sokal and Rohlf 1995). To find which species differ from the others we used a Bonferroni procedure to correct the threshold for multiple comparisons (Quinn and Keough 2002). We calculated a new p-value obtained by division of the significance level (0.05) by number of pair comparisons $(n=3)$. Therefore, each pair comparison for nocturnal activity was tested at 0.017 level of significance. This procedure provides a great control over Type I error and it can be applied to any situation where there are many comparisons (Quinn and Keough 2002).

Because the sampling effort was different between understory and upper canopy, we standardized the number of captures with the sampling effort (number of nets) for statistical analysis. We also used G-test to compare differences in use of vertical space among fruit bat species and differences of captures between understory and upper canopy. Use of vertical space of each fruit bat species was analyzed using a binomial test. Here we compared the z-value calculated with the $\mathrm{z}$ critical value with level of significance at $5 \%(\mathrm{z}=1.96)$. When $\mathrm{z}$ calculated was higher than $\mathrm{z}$ critical value, there was significant difference in the use of vertical space by a given species.

To compare bat capture and fruit availability, we considered only those fruit species present in diet of bats captured in this study. Then, we used the number of species with fruits at each month to correlate with the number of captures of fruit bat species. For this, we used Spearman's correlation coefficient. For G-test, binomial test and correlation analyses we used $95 \%$ confidence interval.

Community diversity was calculated with the ShannonWiener diversity index (Krebs 1998), and we compared this index value with other bat diversity studies in Neotropical region. We also constructed a species accumulation curve with sample-based rarefaction method with $95 \%$ confidence intervals (Gotelli and Colwell 2001). Richness curve (Mao Tau) was calculated as the accumulation curve of species throughout total number of nights $(n=48)$. Species accumulation curves sample-based do not require any resampling, so we made the species accumulation curve using 1000 sample randomizations without replacement (Colwell 2009). To estimate the bat richness we used Chao 1 index (Chao 1984). We chose this index because it is a simple and powerful richness estimator and it is also a conservative estimator, and therefore it estimates a minimum number of species undetected (Gotelli 2008) based on abundance of rare species (Chao 1984). Species accumulation curve and richness estimator were ran using EstimateS 8.2.0 software (Robert K. Colwell - EEB Home, CT, USA) (Colwell 2009). 
Table 1 Bat species, number of captures $(\mathrm{N})$, relative abundance (\%, in parentheses), number of captures in the understory (Und) and in the upper canopy (Can), and number of captures in three periods of one and a half hours in a deciduous forest, Santa Maria, Rio Grande do Sul, southern Brazil.

\begin{tabular}{|c|c|c|c|c|}
\hline Species & Trophic guild & $\mathrm{n}(\%)$ & Und/Can & $\mathrm{I} / \mathrm{II} / \mathrm{III}$ \\
\hline \multicolumn{5}{|l|}{ Phyllostomidae } \\
\hline Artibeus fimbriatus & FRU & $15(15.96)$ & $12 / 3$ & $1 / 2 / 6$ \\
\hline Artibeus lituratus & FRU & $37(39.36)$ & $26 / 11$ & $4 / 1 / 8$ \\
\hline Glossophaga soricina & NEC & $3(3.19)$ & $3 / 0$ & $2 / 0 / 0$ \\
\hline Pygoderma bilabiatum & FRU & $2(2.13)$ & $1 / 1$ & $0 / 1 / 1$ \\
\hline Sturnira lilium & FRU & $28(29.79)$ & $26 / 2$ & $8 / 7 / 2$ \\
\hline \multicolumn{5}{|l|}{ Vespertilionidae } \\
\hline Eptesicus diminutus & INS & $3(3.19)$ & $3 / 0$ & $2 / 0 / 0$ \\
\hline Histiotus montanus & INS & $1(1.06)$ & $0 / 1$ & $0 / 1 / 0$ \\
\hline Myotis levis & INS & $1(1.06)$ & $1 / 0$ & $0 / 0 / 1$ \\
\hline Myotis nigricans & INS & $4(4.26)$ & $4 / 0$ & $0 / 1 / 3$ \\
\hline Total & & $94(100)$ & $76 / 18$ & $17 / 13 / 21$ \\
\hline
\end{tabular}

I, first one and a half hours; II, second one and a half hours; III, one and a half hours before dawn. Here, to nocturnal activity data we considered only those nights sampled during dawn ( $n=24$ nights). FRU, frugivorous; NEC, nectarivorous; INS, insectivorous.

\section{Results}

We captured 94 individuals of nine species and seven genera, belonging to two families (Table 1). Only three recaptures were recorded, one individual of Artibeus fimbriatus (Gray, 1838), one of Sturnira lilium (É. Geoffroy St.-Hilaire, 1810), and one of Eptesicus diminutus (Osgood, 1915). The most abundant species were A. lituratus (Olfers, 1818), S. lilium, and A. fimbriatus. Pygoderma bilabiatum (Wagner, 1843), Myotis levis (Geoffroy St.-Hilaire, 1824), and Histiotus montanus (Philippi and Landbeck, 1861) were captured scarcely. Shannon-Wiener diversity index for this bat community was $\mathrm{H}^{\prime}=1.553$. This index value was low compared to other studies at lower latitudes (Table 2). Four species of fruit bats and four of insectivorous bats were captured, which represent $87 \%$ and $10 \%$ of captures, respectively. Only one nectarivorous species [Glossophaga soricina (Pallas, 1766)] was captured, comprising 3\% of the captures. Species accumulation curve sample-based did not reach an asymptote, but at the 30th night we had already sampled more than $90 \%$ of the bat richness (Figure 2). Chao 1 index estimated 11 bat species within 48 nights sampled, although this index did not reach an asymptote either in the last samples.

Both Artibeus lituratus and Sturnira lilium had a generalist diet, feeding on fruits of Solanaceae, Piperaceae, and Moraceae. Glossophaga soricina, a nectarivorous species, also ate fruits of Ficus luschnathiana and Piper amalago. A. fimbriatus fed only on fruits of $F$. luschnathiana and $F$. adhatodifolia (Tables 3 and 4). Regarding fruit availability, $F$. luschnathiana provided fruits throughout the year whereas other plants had seasonal fructification like species of Piper (Table 4). Moreover, number of captures of fruit bats was not correlated with the number of plants with fruits ( $\mathrm{rs}=0.38$, $\mathrm{p}=0.22$ ).

Fruit bats showed differences in relation to their nocturnal activity period $(\mathrm{G}=12.34, \mathrm{p}=0.015)$ and they were captured more frequently at dawn (Table 1). Sturnira lilium was captured more frequently during the first period after dusk,

Table 2 Bat richness $(\mathrm{S})$ and Shannon-Wiener diversity index $\left(\mathrm{H}^{\prime}\right)$ for this and other studies at different latitudes.

\begin{tabular}{llllll}
\hline Study & Biome & Study site & $\mathrm{S}$ & $\mathrm{H}^{\prime}$ & Coordinates \\
\hline Fleming et al. (1972) & Dry tropical forest & Balboa, Panamá & 27 & 1.89 & $8^{\circ} 57^{\prime} \mathrm{N}, 79^{\circ} 37^{\prime} \mathrm{W}$ \\
Fleming et al. (1972) & Moist tropical forest & Cristobal, Panamá & 31 & 1.98 & $9^{\circ} 20^{\prime} \mathrm{N}, 79^{\circ} 57^{\prime} \mathrm{W}$ \\
Estrada and Coates-Estrada (2002) & Lowland rainforest & Veracruz, México & 30 & 2.30 & $18^{\circ} 25^{\prime} \mathrm{N}, 9^{\circ} 00^{\prime} \mathrm{W}$ \\
Fleming et al. (1972) & Dry tropical forest & Canas, Costa Rica & 27 & 2.07 & $19^{\circ} 28^{\prime} \mathrm{N}, 85^{\circ} 09^{\prime} \mathrm{W}$ \\
Silva (2007) & Caatinga & Pernambuco, Brazil & 21 & 2.39 & $8^{\circ} 08^{\prime} \mathrm{S}, 36^{\circ} 26^{\prime} \mathrm{W}$ \\
Aguirre (2002) & Llanos de Moxos & Espíritu, Bolívia & 38 & 2.88 & $14^{\circ} 08^{\prime} \mathrm{S}, 66^{\circ} 24^{\prime} \mathrm{W}$ \\
Faria et al. (2006) & Atlantic Forest & Bahia, Brazil & 27 & 1.77 & $15^{\circ} 17^{\prime} \mathrm{S}, 39^{\circ} 04^{\prime} \mathrm{W}$ \\
Zortéa and Alho (2008) & Cerrado & Goiás, Brazil & 25 & 2.21 & $18^{\circ} 25^{\prime} \mathrm{S}, 52^{\circ} 00^{\prime} \mathrm{W}$ \\
Pedro et al. (2001) & Atlantic Forest & São Paulo, Brazil & 23 & 2.26 & $22^{\circ} 23^{\prime} \mathrm{S}, 49^{\circ} 40^{\prime} \mathrm{W}$ \\
Esbérard (2003) & Atlantic Forest & Rio de Janeiro, Brazil & 40 & $1.87-2.19$ & $22^{\circ} 55^{\prime} \mathrm{S}-23^{\circ} 58^{\prime} \mathrm{S}$, \\
& & & & $43^{\circ} 16^{\prime} \mathrm{W}-43^{\circ} 14^{\prime} \mathrm{W}$ \\
Bianconi et al. (2004) & Atlantic Forest & Paraná, Brazil & 14 & 1.38 & $23^{\circ} 55^{\prime} \mathrm{S}, 51^{\circ} 57^{\prime} \mathrm{W}$ \\
Alves (2008) & Atlantic Forest & São Paulo, Brazil & 23 & 2.44 & $25^{\circ} 11^{\prime} \mathrm{S}, 47^{\circ} 59^{\prime} \mathrm{W}$ \\
Carvalho et al. (2009) & Restinga & Santa Catarina, Brazil & 9 & 1.75 & $28^{\circ} 37^{\prime} \mathrm{S}, 49^{\circ} 01^{\prime} \mathrm{W}$ \\
This study & Atlantic Forest & Rio Grande do Sul, Brazil & 9 & 1.55 & $29^{\circ} 40^{\prime} \mathrm{S}, 53^{\circ} 43^{\prime} \mathrm{W}$ \\
\hline
\end{tabular}




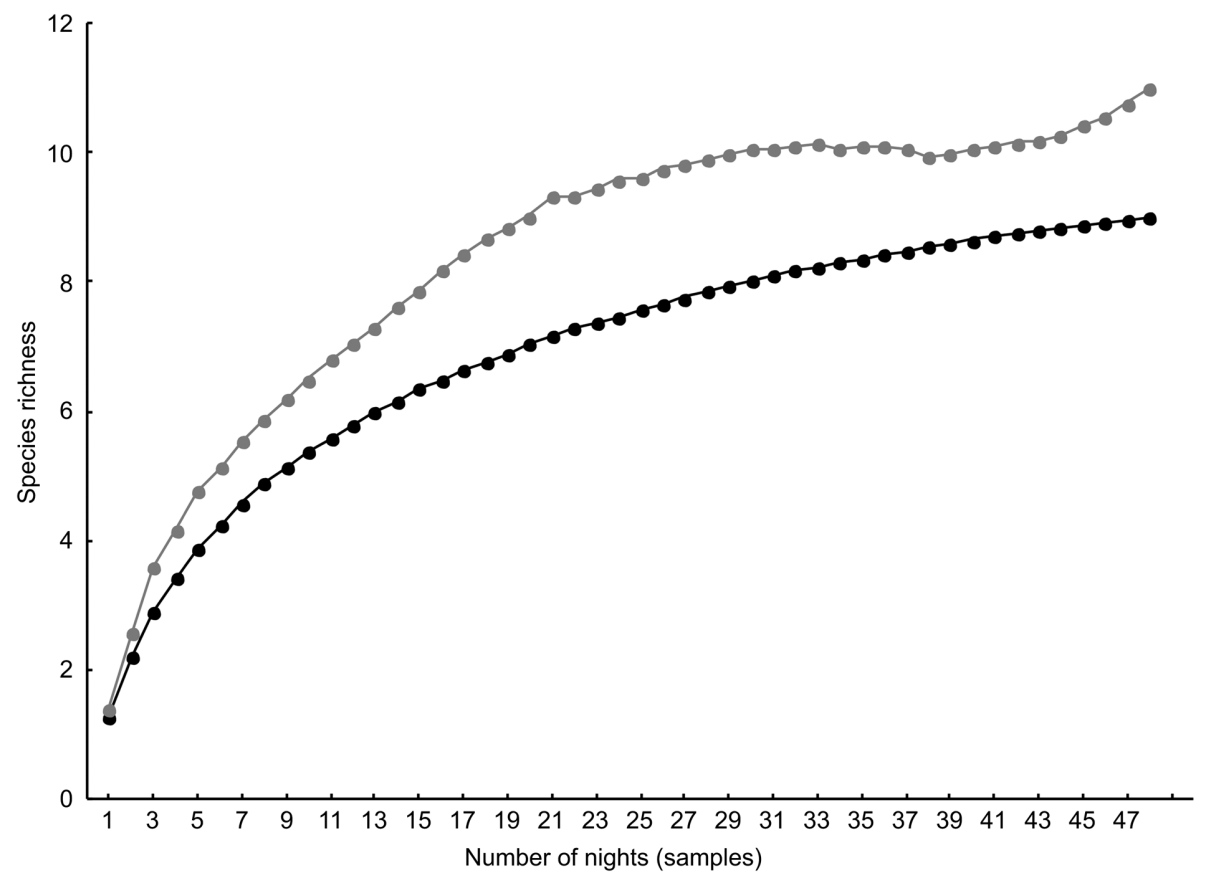

Figure 2 Species accumulation curve of sample-based rarefaction (black line) and estimated richness (gray line) by Chao 1 index (Chao 1984) in a deciduous forest, Santa Maria, Rio Grande do Sul, southern Brazil. The sample-based curve and richness estimator were computed using EstimateS 8.2.0 software (Colwell 2009).

whereas Artibeus lituratus and A. fimbriatus were captured during the second period after dusk and at the end of the night. Nocturnal activity period of S. lilium differed from $A$. fimbriatus $(\mathrm{G}=8.73, \mathrm{p}=0.012)$, and from A. lituratus $(\mathrm{G}=9.3 ; \mathrm{p}=0.009)$, however it was not different between the two species of Artibeus $(\mathrm{G}=0.8, \mathrm{p}=0.67)$.

Upper canopy was used by five species (Table 1). Phyllostomidae used the upper canopy more than Vespertilionidae, represented by only one individual, Histiotus montanus. However, bats used the understory more than the upper canopy $(\mathrm{G}=4.429, \mathrm{p}=0.035)$. Regarding number of captures, Sturnira lilium was captured more frequently in the understory $(n=26)$ than in the upper canopy $(n=2, Z=4.403$, $p<0.001)$. No difference in the use of vertical space was observed for Artibeus lituratus $(\mathrm{Z}=0.154, \mathrm{p}=0.877)$ or A. fimbriatus $(\mathrm{Z}=0.83, \mathrm{p}=0.407)$. Moreover, there was no difference in the use of vertical space among these three fruit bats $(\mathrm{G}=3.092, \mathrm{p}=0.079)$.

\section{Discussion}

Diversity and richness were low compared to other studies in the Atlantic Forest and even other biomes (Table 2). These differences may be related to latitude effect on species distribution because bat species richness tends to decrease with latitude increasing (Willig and Selcer 1989). In fact, bat species richness in southern Brazil is low compared to other

Table 3 Food items consumed by Artibeus fimbriatus ( $\mathrm{n}=3$ fecal samples), A. lituratus $(\mathrm{n}=8)$ and Sturnira lilium ( $\mathrm{n}=13)$ in a deciduous forest, Santa Maria, Rio Grande do Sul, southern Brazil.

\begin{tabular}{|c|c|c|c|c|c|c|}
\hline \multirow[t]{2}{*}{ Item } & \multicolumn{2}{|c|}{ A. fimbriatus } & \multicolumn{2}{|c|}{ A. lituratus } & \multicolumn{2}{|c|}{ S. lilium } \\
\hline & $\mathrm{n}$ & $\%$ & $\mathrm{n}$ & $\%$ & $\mathrm{n}$ & $\%$ \\
\hline Maclura tinctoria (Moraceae) & - & - & 1 & 12.5 & - & - \\
\hline Physalis sp. (Solanaceae) & - & - & - & - & 5 & 35.72 \\
\hline Ficus luschnatiana (Moraceae) & 1 & 33.33 & 4 & 50 & 1 & 7.14 \\
\hline Ficus adhatodifolia (Moraceae) & 2 & 66.67 & 1 & 12.5 & - & - \\
\hline Solanaceae unidentified & - & - & 1 & 12.5 & - & - \\
\hline Piper amalago (Piperaceae) & - & - & - & - & 3 & 21.43 \\
\hline Piper aduncum (Piperaceae) & - & - & 1 & 12.5 & 3 & 21.43 \\
\hline Solanum pseudocapsicum (Solanaceae) & - & - & - & - & 1 & 7.14 \\
\hline Arthropoda & - & - & - & - & 1 & 7.14 \\
\hline
\end{tabular}

n, number of fecal samples; \%, proportion of food item consumed. 


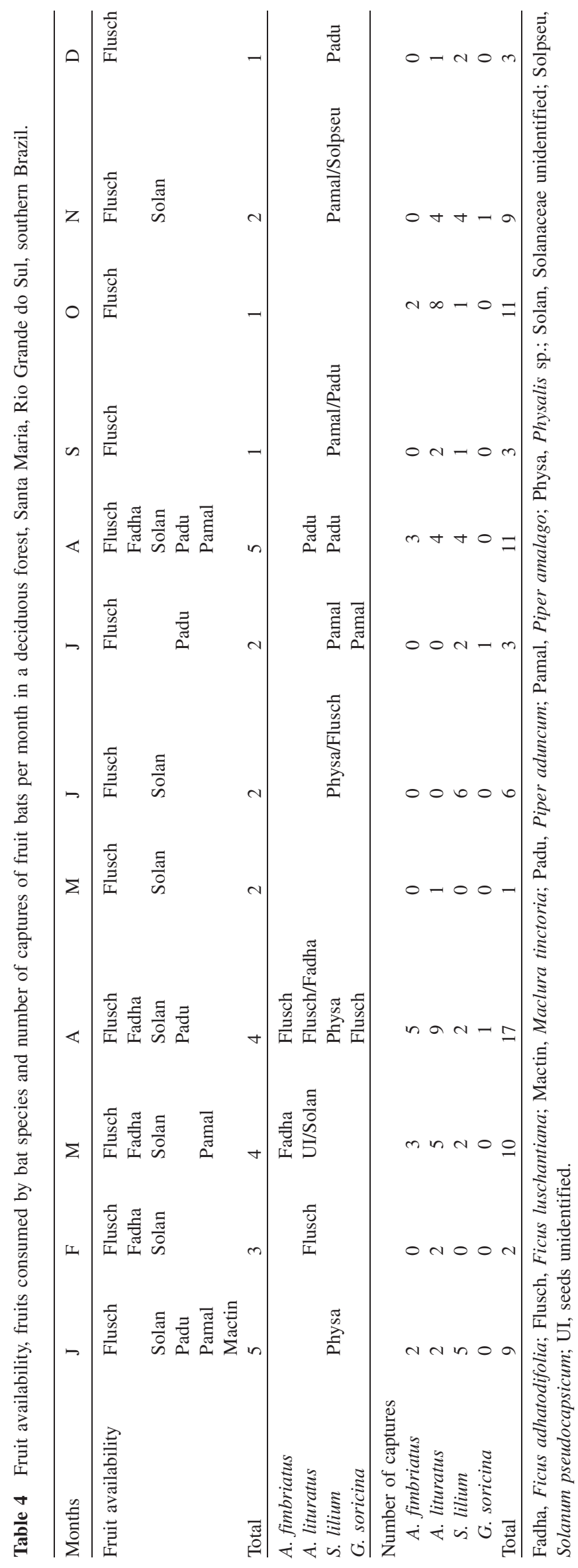

Bereitgestellt von | Instituto Nacional de Pesquisas Espaciai (Instituto Nacional de Pesquisas Espaciai) Angemeldet | 172.16.1.226 
regions of Brazil (Pacheco et al. 2007, Weber 2009) and many species of Phyllostomidae have their austral boundary of distribution coincident with the southern limit of the Atlantic Forest (Fabián et al. 1999). Both species accumulation and richness estimative curves did not reach an asymptote (Figure 2). This means that there are species that we did not catch. Mist-netting is a selective method, which catches more Phyllostomidae than other bat families. So, we believe that the richness of Vespertilionidae and Molossidae is under sampled. Using different sampling methods, such as looking for diurnal roosts and sampling canopies as well as the study of echolocation calls can increase the local bat richness, mainly for Vespertilionidae and Molossidae species (Simmons and Voss 1998, Bernardi et al. 2009). However, we believe that the Phyllostomidae fauna in the study area were well sampled.

Diet of fruit bats was similar to the observations of other studies carried out in the Atlantic Forest (Galetti and Morellato 1994, Mikich 2002, Passos et al. 2003, Mello et al. 2008). Fruit-eater species from different genera fed on different items and therefore may not compete directly for food, as observed with Artibeus lituratus and Sturnira lilium. There was a limited overlap in the diet between these two species, where each one prefers a different resource, even though one species could feed on the preferred resource of another species. Despite the small number of fecal samples from A. fimbriatus, this species may regularly eat fruits of Ficus, which is the typical food of the genus Artibeus (Bonaccorso 1979). Absence of correlation between fruit availability and fruit bat captures may be due to the continuous fruit availability provided by Ficus luschnathiana (Table 4). Although food availability influences bat species composition (Hodgkison et al. 2004) and reproduction (Mello et al. 2004b), fructification of Ficus species provide food throughout the year and can explain why there was no obvious seasonality in the captures of fruit bats.

We have shown that differences in one dimension of the niche, such as food, can help to explain differences in another dimension, such as space use. Fleming (1991) found that habitat use and diet were different among sympatric species and related to body size too. Body size also predicts size of preferred fruits of Ficus by Artibeus and other closely related sympatric bats (Kalko et al. 1996). Congeneric and sympatric bats can feed on the same set of fruits, but there are significant differences on feeding rates (Giannini 1999, Bumrungsri et al. 2007). When diets do not differ locally, species may differ in use of habitat, as shown for sympatric species of Sturnira in an elevational gradient (Giannini 1999).

Sturnira lilium was more active at nightfall whereas both Artibeus species were more active later in the night. This is a well known pattern in bat ecology in the Neotropical region (Marinho-Filho and Sazima 1989, Bernard 2002, Aguiar and Marinho-Filho 2004, Ortencio Filho et al. 2010). High activity before sunrise is common among Neotropical bats (Brown 1968). There are two possible explanations for this pattern - food availability and roost distance. Fruit availability decreases throughout the night and there is no replacement in the same night, hence, bats which forage earlier have more chance to find food. Alternatively, foraging before dawn can be the last chance to find food before going to the roost (Heithaus et al. 1975). In our study area, as S. lilium fed on different fruits from Artibeus, they do not compete for food sources. However, both Artibeus species fed on the similar fruits, and hence we believe the higher activity of these species at the end of the night could be due to food scarcity.

Both Artibeus had similar patterns of activity at the end of the night; a similar overlap has been reported by Ortencio Filho et al. (2010). In Amazonia, Artibeus lituratus also had its activity peak before dawn; however it did not overlap with other Artibeus species. For instance, A. jamaicensis $(=A$. planirostris $)$ and $A$. cinereus were more active during the first hours after nightfall, whereas A. concolor was active throughout night (Bernard 2002). In the Atlantic Forest, Ortencio Filho et al. (2010) found a negative relationship of nocturnal activity among both A. lituratus and A. fimbriatus, with A. planirostris.

Sturnira lilium flew more frequently in the understory than canopy and fed mainly on fruits from pioneer shrubs of Solanaceae and Piper. Bats with smaller body mass and lower wing loading, such as S. lilium appear to have higher maneuverability in the understory than bats with bigger body mass (Norberg and Rayner 1987). Artibeus lituratus and A. fimbriatus did not differ in the use between upper canopy and understory, and A. lituratus fed on Ficus and on some shrubs too. In Amazonia A. lituratus uses the canopy more than the understory (Bernard 2001). This pattern may be related to greater availability of big fleshy fruits in the Amazonian canopy (Gentry and Emmons 1987). In the Atlantic Forest fruit are available in the understory as well as in the canopy. Therefore, in this biome A. lituratus and A. fimbriatus fly at both forest strata, although $S$. lilium flies in the understory as it does in Amazonia.

There was no difference in the use of vertical space among bats. This can have two possible explanations. Fleshy fruit availability in the understory and in the canopy allows bats to forage at both strata (discussed earlier). Canopy in the Atlantic Forest, which ranges from $10 \mathrm{~m}$ to $30 \mathrm{~m}$ height, is quite low. Thus, there is no conspicuous vertical stratification as in Amazonia (Simmons and Voss 1998, Bernard 2001), where the canopy exceeds $30 \mathrm{~m}$.

Despite overlapping in the use of vertical space, Artibeus lituratus and A. fimbriatus may differ in the use of diurnal roosts. It is known that bats having high infestation rates by bat flies use long-term roosts, while bats with low infestation use ephemeral ones (Wenzel and Tipton 1966, Kunz 1982b). In the same study area, an investigation about the relationships between bats and ectoparasite bat flies revealed high rates of parasitism on A. fimbriatus and low rates of parasitism on A. lituratus (Camilotti et al. 2010). Thus, in this area A. fimbriatus may use more durable and resistant roosts, such as caves and tree holes, while A. lituratus may use ephemeral roosts, such as canopy trees. Such difference may allow species coexistence, however, additional studies about the ecological relationships among species of Artibeus should be carried out to corroborate the different space-use hypothesis. 
Number of species, capture frequencies, and habitat use are associated with ecological factors including diet, foraging behavior, and roost selection (Kalko and Handley 2001). Unfortunately, small sample size is a common problem in studies of Neotropical forest bats and makes conclusions about many species problematical (Kalko and Handley 2001). However, we can conclude that niche overlap is greater for related species. Both Artibeus species had similar diet, use of vertical space and nocturnal activity. So, the coexistence between these species can result in a spatial-temporal overlap. Studies about niche overlap that address more than one spatial dimension (such as use of vertical space and diurnal roosts) can elucidate the patterns in use of these resources and also the understanding about bat community composition. Furthermore, it would be interesting to study the relationship between the breadth of ecological niche dimension used by a given species and its local abundance.

\section{Acknowledgments}

We are grateful to Sonia Zanini for material support, Susi Pacheco for the species identification, Cristina Araujo, Stéphane Aulagnier and two anonymous referees for improved suggestions to the paper, and to friends who helped us with the bat capture. To CNPq for financial support to NCC (Edital 06/2008 - Jovem Pesquisador, Processo 569182/2008-5). NCC is a CNPq research fellow.

\section{References}

Aguiar, L.M.S. and J. Marinho-Filho. 2004. Activity patterns of nine phyllostomid bat species in a fragment of the Atlantic Forest in southeastern Brazil. Rev. Bras. Zool. 21: 385-390.

Aguirre, L.F. 2002. Structure of a Neotropical savanna bat community. J. Mammal. 83: 775-784.

Alves, L.A. 2008. Estrutura da comunidade de morcegos (Mammalia: Chiroptera) do Parque Estadual da Ilha do Cardoso, São Paulo, SP. Master Thesis. Universidade Federal do Mato Grosso do Sul. Campo Grande. pp. 40.

Barquez, R.M., N.P. Giannini and M.A. Mares. 1993. Guide to the bats of Argentina/ Guia de los murciélagos de Argentina. Oklahoma Museum of Natural History, Norman. pp. 119.

Bernard, E. 2001. Vertical stratification of bat communities in primary forests of Central Amazon, Brazil. J. Trop. Ecol. 17: 115126.

Bernard, E. 2002. Diet, activity and reproduction of bat species (Mammalia, Chiroptera) in Central Amazonia, Brazil. Rev. Bras. Zool. 19: 173-188.

Bernardi, I.P., J.M.D. Miranda, J. Sponchiado, E. Grotto, F.F. Jacomassa, E.M. Teixeira, S.H. Roani and F.C. Passos. 2009. Morcegos de Frederico Westphalen, Rio Grande do Sul, Brasil (Mammalia: Chiroptera): riqueza e utilização de abrigos. Biota Neotrop. 9: 349-354.

Bianconi, G.V., S.B. Mikich and W.A. Pedro. 2004. Diversidade de morcegos (Mammalia, Chiroptera) em remanescentes florestais do município de Fênix, noroeste do Paraná, Brasil. Rev. Bras. Zool. 21: 943-954.

Bonaccorso, F.J. 1979. Foraging and reproductive ecology in a Panamanian bat community. Bull. Florida State Mus., Biol. Sci. 24: 359-408.
Brown, J.H. 1968. Activity patterns of some Neotropical bats. J. Mammal. 4: 754-757.

Bumrungsri, S., W. Leelapaibul and P.A. Racey. 2007. Resource partitioning in sympatric Cynopterus bats in Lowland Tropical Rain Forest, Thailand. Biotrop. 39: 241-248.

Camilotti, V.L., G. Graciolli, M.M. Weber, J.L.S. Arruda and N.C. Cáceres. 2010. Bat flies from the Deciduous Atlantic Forest in southern Brazil: host-parasite relationships and parasitism rates. Acta Parasitol. 55: 194-200.

Carvalho, F., J.J. Zocche and R.A. Mendonça. 2009. Morcegos (Mammalia, Chiroptera) em restinga no município de Jaguaruna, sul de Santa Catarina, Brasil. Biotemas 22: 193-201.

Chao, A. 1984. Non-parametric estimation of the number of classes in a population. Scand. J. Stat. 11: 265-270.

Colwell, R.K. 2009. EstimateS: statistical estimation of species richness and shared species from samples. Version 8.2. User's Guide and application published at: http://purl.oclc.org/estimates.

Crespo, R.F., S.B. Linhart, R.J. Burns and G.C. Mitchell. 1972. Foraging behavior of the common vampire bat related to moonlight. J. Mammal. 53: 366-368.

Esbérard, C.E.L. 2003. Diversidade de morcegos em área de Mata Atlântica regenerada no sudeste do Brasil. Rev. Bras. Zoociências 5: 189-204.

Estrada, A. and R. Coates-Estrada. 2002. Bats in continuous forest, forest fragments and in an agricultural mosaic habitat-island at Los Tuxtlas, Mexico. Biol. Conserv. 103: 237-245.

Fabián, M.E., A.M. Rui and K.P. Oliveira. 1999. Distribuição geográfica de morcegos Phyllostomidae (Mammalia: Chiroptera) no Rio Grande do Sul, Brasil. Iheringia, Ser. Zool. 87: 143-156.

Faria, D., R.R. Laps, J. Baumgartem and M. Cetra. 2006. Bat and bird assemblages from forests and shade cacao plantations in two contrasting landscapes in the Atlantic Forest of southern Bahia, Brazil. Biodiv. Conserv. 15: 587-612.

Findley, J.S. 1993. Bats: a community perspective. Cambridge University Press, Cambridge. pp. 167.

Fleming, T.H. 1991. The relationship between body size, diet and habitat use in frugivorous bats, genus Carollia (Phyllostomidae). J. Mammal. 72: 493-501.

Fleming, T.H., E.T. Hooper and D.E. Wilson. 1972. Three Central American bat communities: structure, reproductive cycles, and movement patterns. Ecology 53: 556-569.

Fleming, T.H., R. Breitwisch and G.H. Whitesides. 1987. Patterns of tropical vertebrate frugivore diversity. Ann. Rev. Ecol. Syst. 18: $91-109$.

Francis, C.M. 1994. Vertical stratification of fruit bats (Pteropodidae) in Lowland Dipterocarp Rainforest in Malaysia. J. Trop. Ecol. 10: 523-530.

Galetti, M. and L.P.C. Morellato. 1994. Diet of the large fruit-eating bat Artibeus lituratus in a forest fragment in Brazil. Mammalia 58: $661-665$.

Gentry, A.H. and L.H. Emmons. 1987. Geographical variation in fertility, phenology, and composition of the understory of Neotropical forests. Biotrop. 19: 216-227.

Giacomini, H.C. 2007. Os mecanismos de coexistência de espécies como vistos pela teoria ecológica. Oecol. Bras. 11: 521-543.

Giannini, N.P. 1999. Selection of diet and elevation by sympatric species of Sturnira in an Andean rainforest. J. Mammal. 80: $1186-1195$.

Gotelli, N.J. 2008. A primer of ecology. 4th ed. Sinauer Associates Inc., Sunderland, Massachusetts. pp. 290.

Gotelli, N.J. and R.K. Colwell. 2001. Quantifying biodiversity: procedures and pitfalls in the measurement and comparison of species richness. Ecol. Let. 4: 379-391. 
Handley, C.O. Jr., D.E. Wilson and A.L. Gardner. 1991. Demography and natural history of the common fruit bat, Artibeus jamaicensis, on Barro Colorado Island, Panamá. Smiths. Contrib. Zool. 511: 1-173.

Heithaus, E.R., T.H. Fleming, and P.A. Opler. 1975. Foraging patterns and resources utilization in seven species of bats in a seasonal tropical forest. Ecology 56: 841-854.

Henry, M., P. Barrière, A. Gautier-Hion and M. Colyn. 2004. Species composition, abundance and vertical stratification of a bat community (Megachiroptera: Pteropodidae) in a West African rain forest. J. Trop. Ecol. 20: 21-29.

Hodgkison, R., S.T. Balding, A. Zubaid and T.H. Kunz. 2004. Temporal variation in the relative abundance of fruits bats (Megachiroptera: Pteropodidade) in relation to the availability of food in a lowland Malaysian rain forest. Biotropica 36: 522-533.

Hooper, E.T. and J.H. Brown. 1968. Foraging and breeding in two sympatric species of Neotropical bats, genus Noctilio. J. Mammal. 49: 310-312.

Hutchinson, G.E. 1957. Concluding remarks. Cold Spring Harbor Symp. Quantit. Biol. 22: 415-427.

Kalko, E.K.V. and C.O. Handley Jr. 2001. Neotropical bats in the canopy: diversity, community structure, and implications for conservation. Plant Ecol. 153: 319-333.

Kalko, E.K.V., E.A. Herre and C.O. Handley Jr. 1996. Relation of fig fruit characteristics to fruit-eating bats in the New and Old World tropics. J. Biogeogr. 23: 565-576.

Krebs, C.J. 1998. Ecological methodology. 2nd ed. Benjamin Cummings, Menlo Park, California. pp. 620.

Kronfeld-Schor, N. and T. Dayan. 2003. Partitioning of time as an ecological resource. Ann. Rev. Ecol. Evol. Syst. 34: 153-181.

Kunz, T.H. 1982a. Ecology of bats. Plenum Press, New York. pp. 450.

Kunz, T.H. 1982b. Roosting ecology of bats. In: (T.H. Kunz, ed.) Ecology of Bats. Plenum Press, New York. pp. 1-55.

Kunz, T.H. and B. Fenton. 2003. Bat ecology. University of Chicago Press, Chicago. pp. 798.

MacArthur, R.H. 1972. Geographical ecology: patterns in the distribution of species. Harper and Row, New York. pp. 269.

Machado, P.F.S. and S.J. Longhi. 1990. Aspectos florísticos e fitossociológicos do 'Morro do Elefante', Santa Maria, RS. Rev. Centro de Ciênc. Rurais 20: 261-280.

Marchiori, J.N.C. 2004. Fitogeografia do Rio Grande do Sul: Campos Sulinos. EST Edições, Porto Alegre. pp. 110.

Marinho-Filho, J.S. and I. Sazima. 1989. Activity patterns of six phyllostomid bat species in southeastern Brazil. Rev. Bras. Biol. 49: 777-782.

Marinho-Filho, J.S. and I. Sazima. 1998. Brazilian bats and conservation biology: a first survey. In: (T.H. Kunz and P.A. Racey, eds.) Bat Biology and Conservation. Smithsonian Institution Press, Washington, D.C. pp. 282-294.

Mello, M.A.R., G.M. Schittini, P. Selig and H.G. Bergallo. 2004a. Seasonal variation in the diet of Carollia perspicillata (Chiroptera: Phyllostomidae) in an Atlantic Forest area in southeastern Brazil. Mammalia 68: 49-55.

Mello, M.A.R., G.M. Schittini, P. Selig and H.G. Bergallo. 2004b. A test of the effects of climate and fruiting of Piper species (Piperaceae) on reproductive patterns of the bat Carollia perspicillata (Phyllostomidae). Acta Chiropterol. 6: 309-318.

Mello, M.A.R., E.K.V. Kalko and W.R. Silva. 2008. Movements of the bat Sturnira lilium and its role as a seed disperser of Solanaceae in the Brazilian Atlantic Forest. J. Trop. Ecol. 24: 225228.
Mikich, S.B. 2002. A dieta dos morcegos frugívoros (Mammalia, Chiroptera, Phyllostomidae) de um pequeno remanescente de Floresta Estacional Semidecidual do sul do Brasil. Rev. Bras. Zool. 19: 239-249.

Norberg, U.M. and J.M.V. Rayner. 1987. Ecological morphology and flight in bats (Mammalia: Chiroptera): wing adaptations, flight performance, foraging strategy and echolocation. Phil. Trans. Zool. Soc. Lond. B 316: 335-427.

Ortencio Filho, H., N.R. Reis and C.V. Minte-Vera. 2010. Time and seasonal patterns of activity of phyllostomid in fragments of a stational semidecidual forest from the Upper Paraná River, Southern Brazil. Braz. J. Biol. 70: 937-945.

Pacheco, S.M., M.L. Sekiama, K.P.A. Oliveira, F. Quintela, M.M. Weber, R.V. Marques, D. Geiger and D.D. Silveira. 2007. Biogeografia de quirópteros da região sul. Ciênc. Amb. 35: 181202.

Passos, F.C. and G. Graciolli. 2004. Observações da dieta de Artibeus lituratus (Olfers) (Chiroptera, Phyllostomidae) em duas áreas do sul do Brasil. Rev. Bras. Zool. 21: 487-489.

Passos, F.C., W.R. Silva, W.A. Pedro and M.R. Bonin. 2003. Frugivoria em morcegos (Mammalia, Chiroptera) no Parque Estadual Intervales, sudeste do Brasil. Rev. Bras. Zool. 20: 511-517.

Pedro, W.A., F.C. Passos and B.K. Lim. 2001. Morcegos (Chiroptera; Mammalia) da Estação Ecológica dos Caetetus, estado de São Paulo. Chiropt. Neotrop. 7: 136-140.

Pereira, P.R.B., L.R.G. Netto, C.J.A. Borin and M.G.B. Sartori. 1989. Contribuição à geografia física do município de Santa Maria: unidades de paisagem. Geografia - Ensino e Pesquisa 3: 37-68.

Quadros, F.L.F. and V.P. Pillar. 2002. Transições floresta-campo no Rio Grande do Sul. Ciênc. Amb. 24: 109-118.

Quinn, G.P. and M.J. Keough. 2002. Experimental design and data analysis for biologists. Cambridge University Press, Cambridge. pp. 537.

Silva, L.A.M. 2007. Comunidades de morcegos na Caatinga e Brejo de Altitude, no agreste de Pernambuco. Master Thesis. Universidade de Brasília. Brasília. pp. 161.

Simmons, N.B. and R.S. Voss. 1998. The mammals of Paracou, French Guiana: a Neotropical lowland rainforest fauna. Part 1. Bats. Bull. Am. Mus. Nat. Hist. 237: 1-219.

Sokal, R.R. and F.J. Rohlf. 1995. Biometry. W.H. Freeman, New York. pp. 880.

Straube, F.C. and G.V. Bianconi. 2002. Sobre a grandeza e a unidade utilizada para estimar esforço de captura com utilização de redes-de-neblina. Chiropt. Neotrop. 8: 150-152.

Vizotto, L.D. and V.A. Taddei. 1973. Chave para determinação de quirópteros brasileiros. Rev. Fac. Filos. Ciênc. Letras Bol. Ciênc., São José do Rio Preto. 1: 1-72.

Waechter, J.L. 2002. Padrões geográficos na flora atual do Rio Grande do Sul. Ciênc. Amb. 24: 93-108.

Weber, M.M. 2009. Biogeografia de morcegos (Chiroptera) em área de transição floresta-campo no sudeste da América do Sul. Master Thesis. Universidade Federal de Santa Maria. Santa Maria. pp. 71.

Wenzel, R.L. and V.J. Tipton. 1966. Some relationships between mammal hosts and their ectoparasites. In: (R.L. Wenzel and V.J. Tipton, ed.) Ectoparasites of Panama. Field Museum of Natural History, Chicago, Illinois. pp. 677-723.

Willig, M.R. and K.W. Selcer. 1989. Bat species density gradients in the New World: a statistical assessment. J. Biogeogr. 16: 189-195.

Zortéa, M. and C.J.R. Alho. 2008. Bat diversity of a Cerrado habitat in central Brazil. Biodiv. Conserv. 17: 791-805. 